\title{
First record of Phidotricha erigens (Lepidoptera: Pyralidae) feeding on Furcraea spp. in Colombia ${ }^{1}$
}

\author{
Nancy Yohana Grisales Vásquez ${ }^{2} \mathbb{D}$, Luz Fanny Orozco Orozco ${ }^{3 *(\mathbb{D})}$, \\ Carlos Eduardo Giraldo Sánchez $z^{4}$, John Alexander Pulgarín Díaz (D)
}

$10.1590 / 0034-737 X 202168060015$

\begin{abstract}
Fique (Furcraea spp., Agavaceae) is source of natural fiber commuly used for packing in Colombia. However, the crop faces phytosanitary limitations that affect production, with scarce information published in this regard. In an $e x$ situ biological collection of Furcraea spp. larvae of an unidentified species of Pyralidae were found feeding on the reproductive structures of the plants. Then, the aim of this work was to identify and report the species and damage of a potential Furcraea spp. pest in Colombia. The study done in the Research Center La Selva of AGROSAVIA, in the Municipality of Rionegro Antioquia, Colombia $\left(6^{\circ} 07^{\prime} 46^{\prime \prime} \mathrm{N} ;-75^{\circ} 24^{\prime} 55^{\prime \prime} \mathrm{W} ; 2,100 \mathrm{~m}\right.$ elavation). The immature stages were collected from infested bulbils and capsules of Furcraea plants and reared under laboratory conditions $\left(17^{\circ} \mathrm{C}\right.$ and 65\% relative humidity) until adults emerge. The species was identified as Phidotricha erigens Ragonot, 1888 using specialized keys for larva and adult. These larvae adversely affect the sanitary quality of fique seeds, which could affect the expansion of cultivated areas.This paper presents a description of some characters useful for identifying the species in the field.
\end{abstract}

Keywords: Agavaceae; bulbil; damage; fique; natural fiber.

\section{INTRODUCTION}

Historically, natural fibers have been used in the production of clothing, as well as for housing and packing material. In the 1950s, non-biodegradable synthetic fibers displaced them, but inadequate final disposition of nonbiodegradable fibers eventually became an important source of contamination at the global level (Barnes et al., 2009). For this reason, the use of biodegradable alternatives derived from natural fibers is promoted worldwide. In Colombia, Fique (Agavaceae: Furcraea spp.) is the natural fiber most commonly used for packing (Hidalgo et al., 2015; Manimaran et al., 2018); however, this crop faces phytosanitary limitations that affect its production (Linares et al., 2008; Ovalle et al., 2018).

A number of insects are reported to feed on Agavaceae's inflorescences and bulbils worldwide, (Velázquez et al., 2010). Furcraea spp. in Colombia are attacked by Diaspis bromelia Kern, 1978 (Hemiptera: Diaspididae) feeding on leaves and roots; Batrachedra rixator Hodges, 1966 (Lepidoptera: Batrachedridae) feeding on leaves (Pérez, 1964); and Strategus fascinus Burmeister, 1847 (Coleotera: Scarabaeidae) feeding on roots (Neita \& Brett, 2009). In 1942 specimens of an unidentified Pyralidae (Lepidoptera) were collected from Fique, and these are deposited in the Museo Entomológico Francisco Luís Gallego (MEFLG) of Universidad Nacional de Colombia-Sede Medellín. The objective of this study is to identify and report the species and damage of a potential Furcraea spp. pest in Colombia.

\section{MATERIAL AND METHODS}

In the ex situ biological collection of Fique and related species (Furcraea cabuya Trel, Furcraea foetida (L.) Haw, Agave sisalana Perrine, Furcraea spp. and Agave spp.),

Submitted on August 18 th, 2020 and accepted on February 15 th, 2021.

${ }^{1}$ This work is part of the research work devolped by AGROSAVIA and UCO

Corporación Colombiana de Investigación Agropecuaria - AGROSAVIA, Centro de Investigación La Selva, Llanogrande, Rionegro, Antioquia, Colombia. nygrisales@gmail.com

Corporación Colombiana de Investigación Agropecuaria - AGROSAVIA, Centro de Investigación La Selva, Llanogrande, Rionegro, Antioquia, Colombia. Iforozcoo@gmail.com

${ }^{4}$ Universidad Católica de Oriente - UCO, Grupo de Investigación de Sanidad Vegetal, Rionegro, Antioquia, Colombia. cegiral0@gmail.com

${ }^{5}$ Corporación Colombiana de Investigación Agropecuaria - AGROSAVIA, Centro de Investigación El Nus - Vereda ICA, Corregimiento San José del Nus, San Roque, Antioquia, Colombia. jpulgarin@agrosavia.co

"Corresponding author: lforozcoo@gmail.com 
stablished in the Research Center La Selva of AGROSAVIA, in the Municipality of Rionegro Antioquia, Colombia (607`46"N; - $75^{\circ} 24^{\prime} 55^{\prime \prime} \mathrm{W} ; 2,100$ masl), we found some unidentified Pyralidae larvae feeding on the reproductive structures of the plants. We collected infested bulbils and capsules of Furcraea plants, they were taken to the entomology laboratory of the Research Center, to identify and describe their immature stages.

Immature stages were reared on bulbils of the host plant at $17{ }^{\circ} \mathrm{C}$ and $65 \%$ relative humidity until adults emerge. The adults were mounted and photographed under a stereomicroscope (Leica S9i, Germany) to compare their wing characters. Subsequently, the specimens were sexed, with males recognized by their hair-like setae on the antennae (Ragonot, 1888; Velázquez et al., 2010). We preserved last instar larvae in Kahle's solution and identified them following Solis (2006). The specimens were identified as Phidotricha erigens Ragonot, 1888, both by the morphological characters of the larvae (Solis, 2006), as well as by the wing patterns of the adults (Ragonot, 1888; Velázquez et al., 2010). Furthermore, specimen identification was confirmed by Dr. Vitor O. Becker, researcher at the Scientific Institute Uiraçu, Camacan, BA Brazil.

\section{RESULTS AND DISCUSSION}

Phidotricha erigens is a widely distributed polyphagous species (Cock \& Burris, 2013), whose larvae have been reported in crops, such as corn, cotton, ginger, loquat, mango, melon, orange, sweet granadilla,
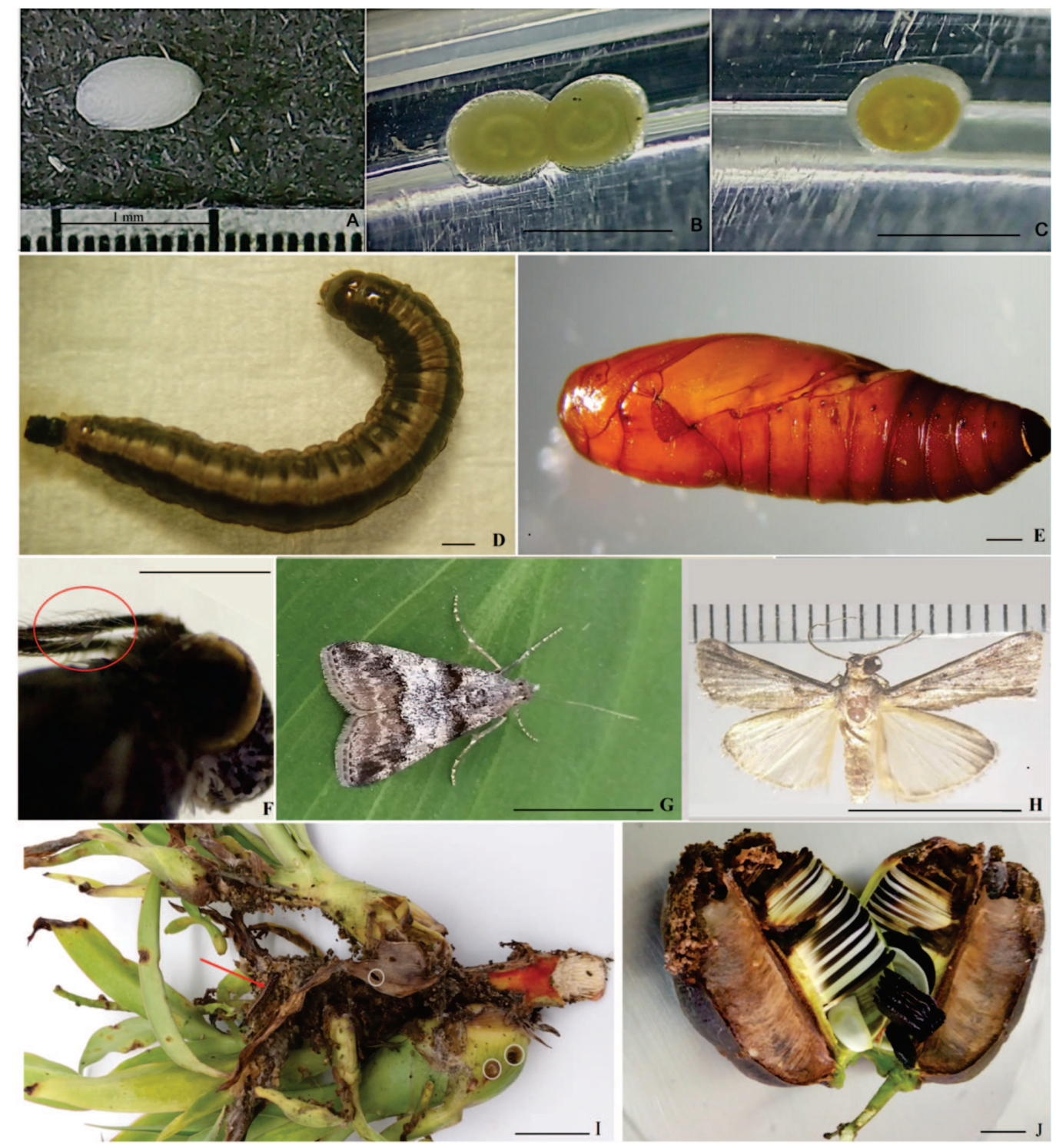

Figure 1: Phidotricha erigens Ragonot 1888. A. Recently laid eggs. B. - C. Eggs. D. Larvae in last instar. E. Pupa. F. Male antenna. G. Life female adult. H. Mounted male. . I. Damage in a bulbil, red arrow and white circles denote the larva and its feeding holes. J. Damage in a capsule. Figure A- F scale bars $=1 \mathrm{~mm}$. Figure G - J scale bars $=1 \mathrm{~cm}$. 
sorghum, tamarind, and white gourd. This is the reason Solis (2006) includes it within the 12 most economically important pest species of Pyralidae. In Agavaceae, this species has been recorded in inflorescences of Agave cocui Trelease (Velázquez et al., 2010), a genus related to Furcraea.

Phidotricha erigens eggs are ellipsoidal with a mean height of $0.88 \mathrm{~mm}$ and a mean width of $0.47 \mathrm{~mm}(\mathrm{n}=13)$; they are white a few hours after oviposition (Figure 1A); two days later, fertile eggs turn yellow with hyaline edges and the presence of the developing larvae is denoted (Figure 1B and Figure 1C); four to six days later, the eggs hatch. The head capsule is pale brown; the body of the larva is light yellow and turns darker while the larva feeds; in later instars, the body coloration pattern becomes dark brown, with pale brown lateral bands on the pleura and the notum (Figure 1D). The pupae are brown in thorax and head regions, and darker towards the last abdomen segments; cremaster black (Figure 1E). Males differ from females because males have plumose antennae (Figure 1F), as reported by Velázquez et al. (2010). The adults are small moths that exhibit sexual dimorphism with female (Figure 1G), darker than male (Figure 1H), forwings are pale-grey with transverse bands white and grey on the dorsal view similar to indicated by Martinez et al. (2019), of $21.32 \mathrm{~mm}(\mathrm{n}=21)$ of wingspan.

Larvae bore small holes and drop excrement (Figure 1I) when building galleries inside the bulbil. Inside the galleries, they leave silk and abundant excrement; however, they also consume leaves and flowers. In mature capsules, larvae feed on the pericarp and seeds; the resulting damage is evidenced by the presence of silk and excrement outside the fruit (Figure 1J).

The presence of P. erigens in Furcraea is associated with a decrease in seed sanitary quality, affecting the expansion of cultivated areas. As it is a polyphagous insect, nonmanagement can generate sources of infestation for nearby productive systems, where the species is considered of economic importance, crops such as citrus, mango, melon, corn and others (Bolzan et al., 2012; Martinez et al., 2019). In this work, we register the presence of $P$. erigens to our knowledge, this seems to be the first report in Colombia as a potential pest in the Furcraea productive system. Also, we reported its presence in Colombia feeding on Furcraea plants in the municipalities of Amalfi, San Vicente, Gómez Plata in Antioquia, and the municipality of Totoró in the Cauca department. The specimens will be deposited in the "Colección Taxonómica Nacional de Insectos Luis María Murillo (CTNI)" of AGROSAVIA, Colombia. Finally, additional work is required to determine its impact in the system and the requirement of the establishment of integrated management programs.

\section{CONCLUSION}

This work records for the first time the presence of $P$. erigens as a potential insect pest in the Furcraea spp. productive system.

\section{ACKNOWLEDGMENTS, FINANCIAL SUPPORT AND FULL DISCLOSURE}

We extend our most gratitude to Clara Inés Medina, Maria Victoria Restrepo, Carlos Velasquez, and the Vitor Becker (Scientific Research Institute Uiraçu, Camacan, BA Brazil). This work belongs to the project "Development of technological bases to stablish a breeding program for the cultivation of fique (Furcraea spp.) in the collection of the research center C.I. La Selva", funded by Corporación Colombiana de Investigación Agropecuaria - AGROSAVIA, Ministerio de Agricultura y Desarrollo Rural (MADR); also, the Sistema de Investigación y Desarrollo, of the Universidad Católica de Oriente - UCO, also funded this work. There is no conflict of interest between the authors in the publication of this work

\section{REFERENCES}

Barnes D, Galgani F, Thompson R \& Barlaz M (2009) Accumulation and fragmentation of plastic debris in global environments. Philosophical Transactions of the Royal Society B, 364:1985-1998.

Bolzan A, Sturza VS \& Dequech STB (2012) Occurrence of Phidotricha erigens Raganot, 1889 (Lepidoptera Pyralidae) in corn in Brazil. Brazilian Journal of Biology, 72:969.

Cock JMW \& Burris DH (2013) Neotropical palm-inflorescence feeding moths (Lepidoptera: Batrachedridae, Blastobasidae, Cosmopterigidae, Gelechiidae, Pyralidae, Tineidae): a review of the literature and new records from Trinidad, West Indies. The Journal of Research on the Lepidoptera, 46:1-21.

Hidalgo M, Muñoz M \& Mina J (2015) Influence of Incorporation of Natural Fibers on the Physical, Mechanical, and Thermal Properties of Composites LDPE-Al Reinforced with Fique Fibers. International Journal of Polymer Science, 2015:1-8.

Linares E, Galeano G, García N \& Figueroa Y (2008) Fibras vegetales utilizadas en artesanías en Colombia. Bogotá, Universidad Nacional de Colombia. 330p.

Manimaran P, Senthamaraikannan P, Sanjay MR, Marichelvam MK \& Mohammad J (2018) Study on Characterizacion of Furcraea foetida new natural fiber as composite reinforcement for lightweight applications. Carbohydrate Polymers, 181:650658 .

Martinez JI, Crane JH, Wasielewski J, Miller JY \& Carrillo D (2019) Lepidoptera pests of sapodilla (Manilkara zapota (L.) van Royen) in south Florida, with some comments on life history and natural control. Insecta Mundi, 739:1-26.

Neita MC \& Brett C (2009) Description of the adult female, larva, pupa, and distribution of Strategus fascinus Burmeister (Scarabaeidae: Dynastinae: Oryctini)." The Coleopterists Bulletin, 63:367-379.

Ovalle SA, Blanco C \& Combariza M (2018) Exploring the composition of raw and delignified Colombian fique fibers, tow and pulp. Cellulose, 25:151-165. 
Pérez J (1964) El Fique su taxonomía, cultivo y tecnología. Medellín, Colina. 128p.

Ragonot EL (1888) M. E. L. Ragonot donne les diagnoses de cinq espèces nouvelles de Microlépidoptères de Porto-Rico. Annales de la Société Entomologique de France, 8:138-140.

Solis MA (2006) Key to selected Pyraloidea (Lepidoptera) larvae intercepted at U.S. ports of entry: revision of Pyraloidea in "Keys to some frequently intercepted lepidopterous larvae" by Weisman 1986. Washington, Department of Agriculture/ National Museum of Natural History. 58p.
Velázquez J, García JL, Romero Y \& Medina M (2010) Phidotricha erigens Ragonot, 1888 (Lepidoptera: Pyralidae), causing damage in Agave cocui Trelease, in Falcon State, Venezuela. Some aspects of its biology and natural control. Entomotropica, 25:117-124. 